Article

\title{
Analysis of Strength and Endurance Values in Schoolchildren Aged 7 to 10 Years in Tolú, Colombia
}

\author{
Carlos Alberto Agudelo Velásquez ${ }^{1, *(1)}$, María Luisa Zagalaz Sánchez ${ }^{2}$ and Félix Zurita Ortega ${ }^{3}$ (1) \\ 1 Instituto de Educación Física, Universidad de Antioquia, 050001 Medellín, Colombia \\ 2 Departamento de Didáctica de la Expresión Musical, Plástica y Corporal, Facultad de Humanidades y \\ Ciencias de la Educación, Universidad de Jaén, 23001 Jaén, Spain \\ 3 Departamento de Didáctica de la Expresión Musical, Plástica y Corporal, Universidad de Granada, \\ 18001 Granada, Spain \\ * Correspondence: carlosa.agudelo@udea.edu.co
}

Received: 30 May 2019; Accepted: 14 August 2019; Published: 16 August 2019

\begin{abstract}
The objective of this study was to describe the state of strength and endurance in schoolchildren aged 7 to 10 years old from the city of Santiago de Tolú, Colombia, and to relate such values to their weights, heights, and body mass index (BMI) values. This was a descriptive, correlational, cross-sectional research study, whose quantitative statistical analysis was compared with studies conducted in Colombia and other countries. Strength was measured by the summation of the segmental dynamometry of the upper and lower limbs, and endurance was measured with a $5 \mathrm{~min}$ continuous run test. This is the first investigation to characterize variables related to physical education and sport in schoolchildren from Tolú. The information collected on the evaluated population may aid in its sustainable human development, since significant differences in height, weight, BMI, strength, and endurance were identified with respect to other national and international populations.
\end{abstract}

Keywords: schoolchildren; endurance; strength; BMI

\section{Introduction}

Aerobic capacity has traditionally been used to assess physical health, although some studies have stated that it should be complemented with other factors [1] such as muscle condition [2], so that muscle metabolism, strength, and metabolic function can be included in studies aimed at identifying optimal lifestyle behaviors [3].

Strength, endurance, and anthropometric variables can be measured to explain the general health state of a population based on the relationship between health and physical education (PE) [4]. Deficiencies in cardiorespiratory capacity and muscular strength are associated with an elevated cardiovascular disease risk [5], and corporal composition may be considered a predictor of maximum $\mathrm{VO}_{2}$ in children from 8 to 11 years old [6]. Sufficient endurance capacity aids in the prevention of cardio-respiratory-type illnesses and even cognitive impairments [7], and low-strength levels can be an indicator of possible metabolic risks [8]. Moreover, aerobic capacity and Body Mass Index (BMI) which act independently [9], are risk factors for the appearance of cardiovascular diseases (CVD) and are determining factors in the detection of talent [10].

Studies in schoolchildren that relate endurance and strength with anthropometric variables permit the influence of PE on these schoolchildren on a daily basis to be understood. Accordingly, through a meta-analysis of 1220 abstracts and more than 850 articles, it was concluded that school-aged children should participate daily in at least $60 \mathrm{~min}$ of moderate to vigorous physical activity, including a wide range of activities with a duration of at least 30 to $45 \mathrm{~min}$ each, three to five days per week, to achieve health goals and benefits [11]. 
Successful educational actions help to encourage health promotion [12] and avoid school failure, since participation in physical activity is positively related to academic performance $[13,14]$. There are interesting antecedents, such as a study presented in Italy, where 120 students participated in walking or running $1 \mathrm{~km}$ for 4 months [15]; in Scotland, where the program called The Daily Mile, which involved 391 children running at their own pace for 15 min daily, obtained significant results in the assessment of body composition and physical condition [16]; and in Ireland, where 90 children participated in a daily 10 min walking program for 5 days, which significantly improved their average number of steps, regardless of gender [17].

Through questionnaires, teachers have validated the concept of basic competencies including in the PE area that should be developed in the schoolchild population [18], but an alternative is to evaluate and compare the students' physical results. This study chose to evaluate strength and endurance to verify the development of healthy competencies in schoolchildren [19]. There are several evaluation systems that can be used to measure the referred capacities, ranging from $30 \mathrm{~s}$ abdominal exercises to assess upright daily functionality [20], up to the application of complete school assessment batteries, such as EUROFIT [21] or batteries of nine elements that include tests of endurance, strength, agility, balance, and motor coordination [22], among others. Such tests have been applied to small children and those aged 5 to 12 years old.

The evaluation of endurance in schoolchildren using continuous or interval methods (Leger \& Lambert test) has shown no significant differences $[23,24]$, and there are tests to measure time over a specific distance $[25,26]$. Additionally, in determining the adequate distance required to develop endurance evaluations in a meta-analysis of tests applied to children and adolescents, studies have found values between $550 \mathrm{~m}$ and 1 mile [27].

There are various methods of strength measurement, such as segmental dynamometry [28], manual pressure and jumps [29], and combinations of manual pressures and segmental extensions conducted with a dynamometer. In a referenced study, it was found that high rates of low muscle aptitude in adulthood are caused by an equivalent low condition in youth [30]. In these methods and others, a dynamometer has been used, so we also used this device in this investigation.

In China, based on a meta-analysis of 18 articles, a campaign was proposed to improve the levels of physical activity of schoolchildren [31]. Additionally, a decrease on average jump height of $16.4 \mathrm{~cm}(11.2 \%)$ was reported in Australian children between 1985 (with 1967 subjects) and 2015 (with 1765 subjects) [30], and a decrease in the level of motor competence was reported in a study conducted on 120 Spanish children [32]. This indicates the need to determine the adequate strength and endurance levels during sensitive phases of development, which are generally defined between 7 and 10 years [33,34] — the ages used for the present study—as these are sensitive ages for motor development and sports initiation [33-36].

In order for a program to be sustainable, we must take into account recommendations such as considering the different characteristics of the students, including enjoyment levels, which diminish negative effects and contribute significantly to the integral personal and emotional development of the students [37]. This study provides information that aids in the recognition of these different characteristics.

The general objective of this study was to analyze endurance and strength variables in schoolchildren aged between 7 and 10 years from Tolú and to compare the collected data with values from other previously studied national and international populations.

\section{Materials and Methods}

\subsection{Design}

This study followed a cross-sectional design using quantitative variables. It aimed to verify the correlations between conditional variables themselves and with respect to anthropometric variables. It sought to analyze whether the results found for the evaluated population exhibit significant 
differences in strength, endurance, weight, and length terms compared with other previously selected national and international populations [38,39].

\subsection{Participants}

The sample included 667 students from the selected northern Colombian city, corresponding to $56 \%$ of the schoolchildren in the population of 1187 schoolchildren in 2015, following the recommendations of García, Reding \& López [40], with a margin of error of 5\%. The minimum population recommended was 290 , which means that the number of subjects evaluated was sufficient.

A total of 344 girls ( $52 \%)$ and 323 boys ( $48 \%$ ) were distributed by age as follows: 123 seven-year-olds (18\%), 179 eight-year-olds (27\%), 174 nine-year-olds (26\%), and 191 ten-year-olds (29\%). Physical condition was assessed by endurance and strength measures, while the BMI, weight, and height were considered anthropometric variables.

\subsection{Variables and Instruments}

Endurance performance was evaluated by an indirect test, a 5 min run test, due to its comfort for participants, ease, and low cost. In accordance with previous studies [25,26], the following equation was used to estimate the $\mathrm{VO}_{2}$ max: $11.6+(\mathrm{d} / \mathrm{t}) \times 0.176$. This equation allows the variables $\mathrm{d}$ (distance in meters) or $\mathrm{t}$ (time in minutes) to be modified, according to the particular needs of each case. For this study, a time of five minutes $(t=5)$ was used, giving the equation $\mathrm{VO}_{2} \max =11.6+(\mathrm{d}) \times 0.0352$. Therefore, when replacing the value (d) of the distance in meters covered by each student, the $\mathrm{VO}_{2} \mathrm{max}$ value was indirectly found.

In Van Mechelen, Hlobil \& Kamper's study [24], a 6 min test was used in schoolchildren aged from 12 to 14 years old, allowing the inference of the viability of the 5 min test used in this study in schoolchildren from 7 to 10 years old. Furthermore, in Li et al. [41], a 6 min test was used for children aged from 7 to 16 years old.

For the strength variable, an isometric measurement was made under the proper safety and objectivity conditions [28,42] with dynamometers calibrated and endorsed by an expert with ISAK II. The assessment of each body segment (arms and legs) in extension and flexion was added, which revealed the Total Force Summation (TTS).

The following anthropometric variables were measured: weight, with Tanita electronic scales; height, with a wood carving meter; and BMI, which was calculated using the equation of Quetelet [43] $\left(\mathrm{BMI}=\right.$ mass $/$ height $\left.{ }^{2}\right)$, with mass measured in kilograms and height measured in meters (Table 1$)$.

Table 1. Operationalization of variables.

\begin{tabular}{|c|c|c|}
\hline Variable & Indicator & Measurement \\
\hline Physical condition capacities & $\begin{array}{ll}\text { - } & \text { Endurance capacity } \\
\text { - } & \text { Strength capacity }\end{array}$ & $\begin{array}{ll}- & 5 \text { min run } \\
\text { - } & \text { Sum of eight isometric } \\
& \text { exercises (dynamometry) }\end{array}$ \\
\hline Anthropometrics & $\begin{array}{ll}\text { - } & \text { Weight } \\
\text { - } & \text { Height } \\
\text { - } & \text { BMI }\end{array}$ & $\begin{array}{ll}\text { - } & \text { Electronic bascule } \\
\text { - } & \text { Wooden cartilage } \\
\text { - } & \text { Direct equation }\end{array}$ \\
\hline
\end{tabular}

\subsection{Procedure}

Participants were assured of anonymity, doubts were clarified by the evaluation team, and all ethical standards required by the 1975 Declaration of Helsinki were followed, with informed consent from those responsible and assent from schoolchildren being given. From there, the results were compared with the national and international results by first adapting the measurements of 
physical condition variables to unify different equations. Then, the existence or absence of significant differences in the values obtained was determined, and the internal correlations of the referred variables were calculated.

\subsection{Data Analysis}

IBM SPSS Statistics version 24 was used for data analysis after verifying that the assumption of normality was not met for the variables. To measure correlations, Spearman's Rho was used, and the Mann-Whitney U test was employed to compare the differences between variables, as non-parametric statistics. In order to facilitate such processes, the percentiles of the analyzed variables were found.

\subsection{Boundaries}

A limitation of the current study is that the comparison made within studies varies depending on the case, especially due to the diversity of the measurement methodologies. The greatest relevance of this study is that it is the first for this population of northern Colombia, which can ensure that issues of the sustainability of adequate policies are addressed for the welfare of this community.

\section{Results}

The null hypothesis (Ho) — "there are no significant differences in height, weight, BMI, strength, and endurance of the population of Tolú from 7 to 10 years old, compared with other national and international populations" - was rejected, which means that the lower conditional and anthropometric values of the variables analyzed in the schoolchildren are evident. The hypothesis that "there is no correlation between BMI and strength" was also rejected, and the null hypothesis (Ho) was accepted: "There is no correlation between $\mathrm{BMI}$ and $\mathrm{VO}_{2} \mathrm{max}$, as an indicator of endurance". This means that intrinsic correlations are important between BMI and strength and also between the two conditional variables (strength and endurance), but not between BMI and endurance.

The descriptions of the five (5) variables considered-weight, $\mathrm{BMI}$, height, endurance $\left(\mathrm{VO}_{2} \mathrm{max}\right)$, and strength (segmental summation of strength) - were made according to the results of normality using medians and interquartile ranges.

Table 2 shows the following median values for the study population: weight, $27.4 \mathrm{~kg}( \pm 8.7)$; height, $130 \mathrm{~cm}( \pm 13) ; \mathrm{BMI}, 16$ ( \pm 2.98$) ; \mathrm{VO}_{2} \max , 34.99 \mathrm{~mL} / \mathrm{kg} / \mathrm{min}( \pm 5.81)$; and strength, $100.9 \mathrm{~kg}-\mathrm{f}( \pm 28.1)$.

Table 2. Statistical descriptions of the variables.

\begin{tabular}{ccccc}
\hline \multirow{2}{*}{ Variable } & Statistical & Girls & Boys \\
\hline \multirow{2}{*}{ Weight } & Medium & 27.4 & 27.8 & 27.1 \\
& Interquartile Range & 8.7 & 10.15 & 7.3 \\
\hline \multirow{2}{*}{ Height $(\mathrm{cm})$} & Medium & 130 & 131 & 130 \\
& Interquartile Range & 13 & 14 & 12 \\
\hline \multirow{2}{*}{ Body Mass Index (BMI) } & Medium & 16.29 & 16.38 & 16.25 \\
& Interquartile Range & 2.98 & 3 & 3.08 \\
\hline \multirow{2}{*}{$\mathrm{VO}_{2}$ max } & Medium & 34.99 & 34.74 & 35.50 \\
& Interquartile Range & 5.81 & 5.61 & 6.2 \\
\hline \multirow{2}{*}{ Sum of strength } & Medium & 100.9 & 96.85 & 103.7 \\
& Interquartile Range & 28.1 & 30.1 & 28 \\
\hline
\end{tabular}

Table 3 presents the correlations of anthropometric and conditional variables, using the BMI as a summary of the anthropometric variables. 
Table 3. Correlations.

\begin{tabular}{cccc}
\hline Spearman's Rho & BMI-VO $_{2}$ & BMI- $\sum$ Strength & VO $_{2}-\sum$ Strength \\
\hline Coefficient of correlation & -0.036 & $0.321^{* *}$ & $0.238^{* *}$ \\
\hline Bilateral Significance & 0.353 & 0.000 & 0.000 \\
\hline & ${ }^{* *}$ Highly significant result. &
\end{tabular}

For this population, the correlations were verified. The correlations between BMI and summation of strength, and $\mathrm{VO}_{2}$ max and summation of strength, were positive and highly significant $(p<0.01 * *)$, which means that the BMI for the schoolchildren evaluated was a determinant of the sum of forces presented in the dynamometry. Likewise, strength and endurance were highly related in this group, while the correlation between $\mathrm{BMI}$ and $\mathrm{VO}_{2}$ max did not present a statistically significant correlation, $(p=0.353)$. In conclusion, the conditional variables were correlated, and the BMI was highly correlated with strength but not with endurance.

Table 4 shows the differences in height and weight between the selected schoolchildren and various populations. The difference with the Dutch [44] is highly significant $(p<0.01 * *)$, and the differences with Euskadi (Basque) schoolchildren [45] and the standardized tables in Colombia [43] are significant for both height and weight, and as a consequence, there is also a significant difference in the BMI $\left(p<0.05^{*}\right)$.

Table 4. Differences in the median values of anthropometric variables, as assessed by the Mann-Whitney $\mathrm{U}$ test.

\begin{tabular}{cccccc}
\hline & \multicolumn{2}{c}{ International Studies } & \multicolumn{3}{c}{ National Studies } \\
\cline { 2 - 6 } $\begin{array}{c}\text { Tolú vs. Other } \\
\text { Population }\end{array}$ & $\begin{array}{c}\text { Weight and } \\
\text { Height in } \\
\text { Dutch School } \\
\text { Children [44] }\end{array}$ & $\begin{array}{c}\text { Weight and } \\
\text { Height in } \\
\text { Spaniards School } \\
\text { Children [45] }\end{array}$ & Height [43] & Weight [43] & BMI [43] \\
\hline Significance & $0.000^{* *}$ & $0.012^{*}$ & $0.041 *$ & $0.018^{*}$ & $0.21^{*}$ \\
\hline
\end{tabular}

* Significant. ${ }^{* *}$ Highly significant result.

Table 5 shows differences in endurance between the referenced values of Zintl [46] and the study by Jáuregui \& Ordoñez [43] with significant differences indicated by $p<0.05^{*}$. Although there are no statistical differences between the strength in the Swedish strength study [28] and the endurance study developed in Armenia, Colombia [47], Table 6 highlights the comparison of the measurements of strength between Swedes and Colombians due to the significant differences after 8 years of age.

Table 5. Differences in the median values of conditional variables, as assessed by the Mann-Whitney U test.

\begin{tabular}{ccccc}
\hline \multirow{2}{*}{$\begin{array}{c}\text { Tolú vs. Other } \\
\text { Population }\end{array}$} & $\begin{array}{c}\text { International Studies } \\
\text { Strength in Swedish } \\
\text { Children [28] }\end{array}$ & $\begin{array}{c}\text { Endurance } \\
\text { Referenced with } \\
\text { Zintl Values [46] }\end{array}$ & $\begin{array}{c}\text { Endurance in } \\
\text { Armenian (Col) 10 } \\
\text { Year Olds [47] }\end{array}$ & VO O $_{2}$ max (Col) [43] \\
\hline Significance & 0.144 & $0.012 *$ & 0.180 & $0.012 *$ \\
\hline
\end{tabular}

Evidence shows that schoolchildren are distanced from the referenced population (Swedish) in their strength values through ageing. Seven-year olds exhibit a positive difference in favor of Tolú of $1.3 \%$, and eight-year-old Swedish children are $21 \%$ stronger, which increases to $29 \%$ for nine-year-olds and $33 \%$ for ten-year-olds. 
Table 6. Table with average values of strength summation by age, built based on data from Nyström et al. (2006) [28].

\begin{tabular}{ccccc}
\hline EStrength & 7 Years Old & 8 Years Old & 9 Years Old & 10 Years Old \\
\hline Tolú & 82.1 & 93.3 & 102.8 & 115.1 \\
\hline Nyström & 81.4 & 113.6 & 133 & 152.7 \\
\hline
\end{tabular}

\section{Discussion}

Through comparing the heights and weights with data collected by Jáuregui \& Ordoñez [43] in a classic study conducted in Colombia that is still valid because it has not been repeated, it can be affirmed that schoolchildren in Tolú are taller and heavier than those evaluated in 1994, except for children aged 7 years old. The BMI values are higher in the selected population at all ages, and in both studies, these values were shown to increase with age, equally by gender, except for in seven-year-olds in Tolú, where boys were shown to have lower BMI values than girls.

The finding of homogeneity by gender does not coincide with data collected by Malina, Choh, Czerwinski \& Chumlea [48], where significant differences were seen for height in favor of boys.

Contreras, González \& Pastor [49] assessed $\mathrm{VO}_{2}$ max. In children, the values are $40-48 \mathrm{~mL} / \mathrm{kg} / \mathrm{min}$ in untrained individuals and up to $60 \mathrm{~mL} / \mathrm{kg} / \mathrm{min}$ in trained individuals. Thus, the evaluated population was shown to have low $\mathrm{VO}_{2}$ max values, with values of $37 \mathrm{~mL} / \mathrm{kg} / \mathrm{min}$ in boys and $36 \mathrm{~mL} / \mathrm{kg} / \mathrm{min}$ in girls.

Correlated with the study by Jáuregui \& Ordoñez [43], endurance is much lower in northern Colombian schoolchildren in all ages and for both genders. To establish this difference, the instruments were adjusted and the same equation was applied, modified from Balke, since, for the standardized tests in Colombia in 1994, the time was measured using a $1000 \mathrm{~m}$ test, and for the selected schoolchildren, the distance was measured with a 5 min running test. Significant statistical differences were found (Table 5), which allow us to conclude that the students of Tolú from 7 to 10 years have better heights and weights, but significantly less endurance, which was ratified by the low values of endurance by age according to the tables of Zintl [46].

A study of oxygen consumption values developed in Colombia [50] did not show significant differences by age, which does not coincide with the present study, where consumption increased significantly by age in both genders. Correa [51] presented a study of Colombian soccer players aged 7 to 16 years old, which also found minimal differences in oxygen consumption among those aged between 7 and 10 years old. This is probably because both studies used the Course Navette, in contrast with the equation used in this study, which appears to be more sensitive by age.

The use of instruments with little risk and physical impact coincides with the recommendations to evaluate endurance by avoiding physiological risks [52], preventing the development of safe programs and the evaluation of strength [53].

Faigenbaum, Westcott \& Miliken [54] conducted an evaluation using the 1 MRI (Maximum Repetition or 1RM) strength test directly in trained and untrained healthy children and provided evidence that there are no risks from using this type of test. This evidence, plus the fact that the present study was performed through MRI in dynamometry in a sitting position, can guarantee optimal safety conditions to evaluate the strength.

Comparing the results obtained with the growth trends in strength found by Beenakker et al. [44], where boys by age were shown to develop strength faster than girls, this trend did not coincide with our findings, where it is evident that the median of female strength values increases with age almost equivalently with that of male values. This finding coincides with data collected by Hébet, Maltais, Lepage, Saulnier \& Crete [55].

This finding that strength increases with age in both genders also coincides with a study by Nyström et al. [28] on isometric force presented for schoolchildren of both genders. 
This study of children aged 7 to 10 years of age is in accordance with the high metabolic risk indicated in low-income young Colombians in Cohen et al.'s study [8] of 669 children, with an average age of 11.5 years, and this statement also affirms that controlled manual dynamometry can be used to assess metabolic risk.

\section{Conclusions}

This study showed that in a population of schoolchildren from northern Colombian, subjects with properly developed strength tend to have higher $\mathrm{BMI}$ and endurance values $\left(\mathrm{VO}_{2} \mathrm{max}\right)$, despite $\mathrm{BMI}$ values being unrelated to endurance. The northern Colombia (Caribbean) schoolchildren population presented higher height, weight, and BMI values but also a lower endurance capacity than those collected from Colombian schoolchildren with the Standardized Tests for Colombia [43], which implies the need to carry out actions to improve this situation. In terms of strength, a significant decrease was found in isometric strength values, which reached up to 33\% of the values collected from 10-year-old schoolchildren in a Swedish population in a similar study.

Even though schoolchildren in Tolú are at levels considered normal according to resolution 00002465 of the Ministry of Health and Social Protection of Colombia from 14 June 2016 [56] for height and weight, it is evident that they are weaker than similar populations in other countries. Also, the heights, weights, and BMI values of the selected schoolchildren were significantly different from those of other Colombian populations. Moreover, they were shown to have deficiencies in endurance and strength, and therefore, state intervention is imperative, both to enable the emergence of sporting talents and to prevent deficiencies and even possible future diseases.

The analysis coincides with the argument presented by Peréz-Ordaz, Aznar, Nuviala, and Nuviala [57] that physical capabilities contribute to the sustainable development of education. Thus, physical education should be encouraged with the objective of creating healthy lifestyle habits that lead to better human development.

\section{Practical Applications}

The selected schoolchildren included in this study had low levels of physical development, with heights and weights apparently being a reflection of the low level of physical activity carried out in this population.

It is highly recommended that complementary activities that stimulate greater physical, anthropometric, and human development in this population be carried out. Therefore, more and better sport, recreation, and physical activity programs should be implemented in the region.

Author Contributions: All authors contributed to the development of the research and writing of the article.

Funding: This research was supported by the company PREVISERD LTDA in the evaluation of the subjects.

Acknowledgments: This research was supported by the company PREVISERD LTDA in the evaluation of the subjects.

Conflicts of Interest: The authors declare no conflict of interest.

\section{References}

1. Mintjens, S.; Menting, M.D.; Daams, J.G.; van Poppel, M.N.; Roseboom, T.J.; Gemke, R.J. Reply to tarp et al.: Comment on: "Cardiorespiratory fitness in childhood and adolescence affects future cardiovascular risk factors: A systematic review of longitudinal studies". Sports Med. 2019, 49, 163-165. [CrossRef] [PubMed]

2. Molina, J.; Morente, J.; Díaz, M. Effect of a physical activity program on aerobic performance and hand-grip strength in children. Arch. Med. Deporte 2014, 31, 9-13.

3. Wolfe, R.R. The underappreciated role of muscle in health and disease. Am. J. Clin. Nutr. 2006, 84, 475-482. [CrossRef] [PubMed] 
4. Cattuzzo, M.T.; Dos Santos, R.; Ré, A.H.; De Oliveira, I.S.; Melo, B.M.; De Sousa, M.; De Araújo, R.C.; Stodden, D. Motor competence and health related physical fitness in youth: A systematic review. J. Sci. Med. Sport 2016, 19, 123-129. [CrossRef] [PubMed]

5. Ruiz, J.R.; Sui, X.; Lobelo, F.; Morrow, J.R.; Jackson, A.W. Association between muscular strength and mortality in men: Prospective cohort study. BMJ 2008, 337, a439. [CrossRef] [PubMed]

6. Dencker, M.; Thorsson, O.; Karlsson, M.K.; Lindén, C.; Eiberg, S.; Wollmer, P.; Andersen, L.B. Gender differences and determinants of aerobic fitness in children aged 8-11 years. Eur. J. Appl. Physiol. 2007, 99, 19-26. [CrossRef] [PubMed]

7. Fedewa, A.L.; Ahn, S. The effects of physical activity and physical fitness on children's achievement and cognitive outcomes: A meta-analysis. Res. Q. Exerc. Sport 2011, 82, 521-535. [CrossRef] [PubMed]

8. Cohen, D.D.; Gómez, D.; Camacho, P.A.; Pinzón, S.; Hormiga, C.; Trejos, J.; López, P. Low muscle strength is associated with metabolic risk factors in colombian children: The ACFIES study. PLoS ONE 2014, 9, e93150. [CrossRef] [PubMed]

9. Eisenmann, J.C.; Katzmarzyk, P.T.; Perusse, L.; Tremblay, A.; Després, J.P.; Bouchard, C. Aerobic fitness, body mass index, and CVD risk factors among adolescents: The Québec family study. Int. J. Obes. 2005, 29, 1077-1083. [CrossRef]

10. Till, K.; Cobley, S.; O’Hara, J.; Brightmore, A.; Cooke, C.; Chapman, C.H. Using anthropometric and performance characteristics to predict selection in junior UK Rugby League players. J. Sci. Med. Sport 2011, 14, 264-269. [CrossRef]

11. Strong, W.B.; Malina, R.M.; Blimkie, C.J.; Daniels, S.R.; Dishman, R.K.; Gutin, B.; Trudeau, F. Evidence-based physical activity for school-age youth. J. Pediatr. 2005, 146, 732-737. [CrossRef] [PubMed]

12. Aubert, A.; Bizkarra, M.; Calvo, J. Actuaciones educativas de éxito desde la educación física. Retos 2014, 25, 144-148.

13. Coe, D.P.; Pivarnik, J.M.; Womack, C.J.; Reeves, M.J.; Malina, R.M. Effect of physical education and activity levels on academic achievement in children. Med. Sci. Sports Exerc. 2006, 38, 1515-1519. [CrossRef] [PubMed]

14. Singh, A.; Uijtdewilligen, L.; Twisk, J.W.; Van Mechelen, W.; Chinapaw, M.J. Physical activity and performance at school: A systematic review of the literature including a methodological quality assessment. Arch. Pediatr. Adolesc. Med. 2012, 166, 49-55. [CrossRef] [PubMed]

15. Brustio, P.R.; Moisè, P.; Marasso, D.; Miglio, F.; Rainoldi, A.; Boccia, G. Feasibility of implementing an outdoor walking break in Italian middle schools. PLoS ONE 2018, 13, e0202091. [CrossRef] [PubMed]

16. Chesham, R.A.; Booth, J.N.; Sweeney, E.L.; Ryde, G.C.; Gorely, T.; Brooks, N.E.; Moran, C.N. The Daily Mile makes primary school children more active, less sedentary and improves their fitness and body composition: A quasi-experimental pilot study. BMC Med. 2018, 16, 64. [CrossRef] [PubMed]

17. Murtagh, E.; Mulvihill, M.; Markey, O. Bizzy Break! The effect of a classroombased activity break on in-school physical activity levels of primary school children. Pediatr. Exerc. Sci. 2013, 25, 300-307. [CrossRef]

18. Lleixá, T.; Capllonch, M.; González, C. Competencias básicas y programación de Educación Física. Validación de un cuestionario diagnóstico. Retos 2015, 27, 52-57.

19. López, V.M.; Pérez, D.; Manrique, J.C.; Monjas, R. Los retos de la Educación Física en el Siglo XXI. Retos 2016, 29, 182-187.

20. Dueñas, L.E. Valoración de la Fuerza Resistencia en Estudiantes de 7 a 18 años de los Colegios Distritales de la Ciudad de Bogotá por Medio del Test de Abdominales en 30 Segundos. Master's Thesis, Universidad Santo Tomás, Bogotá, Colombia, 2016.

21. Fjørtoft, I. Motor fitness in pre-primary school children: The EUROFIT motor fitness test explored on 5-7-year-old children. Pediatr. Exerc. Sci. 2000, 12, 424-436. [CrossRef]

22. Fjørtoft, I.; Pedersen, A.V.; Sigmundsson, H.; Vereijken, B. Measuring physical fitness in children who are 5 to 12 years old with a test battery that is functional and easy to administer. Phys. Ther. 2011, 9, 1087-1095. [CrossRef]

23. Arsa, G.; Lanza, F.C.; Cambri, L.T.; Antonio, E.L.; Murad, N.; De Mello, M.T.; Serra, A.J. Predicted equation for VO 2 based on a 20-m multistage shuttle run test for children. Int. J. Sports Med. 2018, 39, 1049-1054.

24. Van Mechelen, H.; Hlobil, H.; Kemper, H. Validation of two running tests as estimates of maximal aerobic power in children. Eur. J. Appl. Physiol. 1986, 55, 503-506. [CrossRef]

25. Márquez, J.; Díaz, G. Behavior of indirect maximal Oxygen uptake on users of de PROSA Program at Universidad de Antioquia, Medellín, Colombia. Colomb. Med. 2011, 42, 327-333. 
26. Díaz, D.; Valbuena, L.; Pérez, J.; Cardona, O. Correlación entre la ergoespirometría y la prueba de los 2000 metros. Rev. Ant. Med. Dep. 2000, 3, 17-20.

27. Batista, M.B.; Romanzini, C.L.; Castro, J.; Ronque, E. Validity of field tests to estimate cardiorespiratory fitness in children and adolescents: A systematic review. Rev. Paul. Pediatr. 2017, 32, 222-233. [CrossRef]

28. Nyström, N.; Kroskmark, A.K. Isometric muscle torque in children 5 to 15 years of age: Normative data. Arch. Phys. Med. Rehabil. 2006, 87, 1091-1099.

29. Pacheco, J.D.; Ramírez, R.; Correa, J.E. General strength index and adiposity as a measure of health-related physical fitness among children and adolescents from Bogotá, Colombia: The FUPRECOL study. Nutr. Hosp. 2016, 33, 556-564.

30. Fraser, B.J.; Blizzard, L.; Tomkinson, G.R.; Lycett, K.; Wake, M.; Burgner, D.; Magnussen, C.G. The great leap backward: Changes in the jumping performance of australian children aged 11-12-years between 1985 and 2015. J. Sports Sci. 2019, 37, 748-754. [CrossRef]

31. Wang, N.; He, J.; Wang, Z.; Miao, R.; Leslie, E.; Xu, F. The prevalence of sufficient physical activity among primary and high school students in Mainland China: A systematic review and meta-analysis. Public Health 2018, 163, 67-75. [CrossRef]

32. Gómez, M. Problemas Evolutivos de Coordinación Motriz y Percepción de Competencia en el Alumnado de Primer curso de Educación Secundaria Obligatoria en la Clase de Educación Física. Ph.D. Thesis, Universidad Complutense de Madrid, Madrid, Spain, 2004.

33. Avella, E.; Maldonado, C.; Ramos, S. Entrenamiento Deportivo con Niños; Kinesis: Armenia, Colombia, 2015.

34. Uribe, I.; Gaviria, D.; Chaverra, B.; Vélez, P. Guía Curricular Para la Educación Física; Editorial Universidad de Antioquia; Gobernación de Antioquia, Secretaría de Educación para la Cultura: Medellín, Colombia, 2009.

35. Blanco, A. Temario de Oposición Secundaria; INDE: Barcelona, Spain, 1994.

36. Martin, D.; Nicolaus, J.; Ostrowski, C.H.; Rost, K. Metodología General del Entrenamiento Infantil y Juvenil; Paidotribo: Barcelona, Spain, 2004.

37. Gil, P.; Cejudo, J.; Martínez, J.M.; López, G.F. Impact of the body mass index on affective development in physical education. Sustainability 2019, 11, 2459.

38. Hernández, R.; Fernández, C.; Baptista, P. Metodología de la Investigación; McGraw-Hill: México DF, Mexico, 2006.

39. Thomas, J.; Nelson, J. Métodos de Investigación en Actividad Física; Paidotribo: Barcelona, Spain, 2006.

40. García, J.A.; Reding, A.; López, J.C. Cálculo del tamaño de la muestra en investigación en educación médica. Investig. Ed. Med. 2013, 2, 217-224. [CrossRef]

41. Li, A.M.; Yin, J.; Au, J.T.; Therefore, H.K.; Tsang, T.; Wong, E.; Fok, T.F.; Ng, P.C. Standard reference for the six-minute-walk test in healthy children aged 7 to 16 years. Am. J. Respir. Crit. Care Med. 2007, 176, 174-180. [CrossRef]

42. Marrodán, M.; Romero, J.; Moreno, M.; Mesa, M.; Cabañas, M.; Pacheco, J.; González, M. Dinamometría en niños y jóvenes de entre 6 y 18 años: Valores de referencia. Asociación con tamaño y composición corporal. Ann. Pediatr. 2009, 70, 340-348. [CrossRef]

43. Jáuregui, O.; Ordoñez, N. Aptitud física. Pruebas Estandarizadas en Colombia; Coldeportes: Bogotá, Colombia, 1994.

44. Beenakker, E.A.; Van der Hoeven, J.H.; Fock, J.M.; Maurits, N.M. Reference values of maximum isometric muscle force obtained in 270 children aged 4-16 years by hand-held dynamometry. Neuromuscul. Disord. 2001, 11, 441-446. [CrossRef]

45. Sainz, R.M. La Batería Eurofit en Euskadi; Instituto Vasco de Educación Fisica: Vitoria-Gasteiz, Spain, 1996.

46. Zintl, F. Entrenamiento de la Resistencia; Martínez Roca: Barcelona, Spain, 1991.

47. Palomino, C.; Ayala, J. Composición corporal y capacidades condicionales en estudiantes de Instituciones Públicas de Armenia. Des-Encuentros 2013, 10, 544-555.

48. Malina, R.; Choh, C.; Czerwinski, S.; Chumlea, W. Validation of maturity offset in the fels longitudinal study. Pediatr. Exerc. Sci. 2016, 28, 439-455. [CrossRef]

49. Contreras, O.R.; González, S.; Pastor, J.C. El trabajo de resistencia en educación primaria. Tándem 2006, $22,17-28$.

50. Guio, F. Evaluación de las capacidades físicas condicionales en jóvenes bogotanos aplicables en espacios y condiciones limitadas. Hallazgos 2007, 4, 35-60. 
51. Correa, J. Determinación del perfil antropométrico y cualidades físicas de niños futbolistas de Bogotá. Rev. Cienc. Salud 2008, 6, 74-84.

52. Rivera, A. Evaluación de la Resistencia Aeróbica en Niños Deportistas de 6 a 12 años de edad del Área Metropolitana de Monterrey-México. Master's Thesis, Universidad Autónoma de Nuevo León, San Nicolás de los Garza, Mexico, 1997.

53. Comité Nacional de Medicina del Deporte Infantojuvenil. Entrenamiento de la fuerza en niños y adolescentes: Beneficios, riesgos y recomendaciones. Arch. Argent. Pediatr. 2018, 116, 582-591.

54. Faigenbaum, A.D.; Westcott, W.L.; Miliken, L.A. Maximal strength testing in healthy children. J. Strength Cond. Res. 2003, 17, 162-166.

55. Hébet, L.; Maltais, D.; Lepage, C.; Saulnier, J.; Crete, M. Habd-held dynamometry isometric torque reference values for children and adolescent. Pediatr. Phys. Ther. 2015, 27, 414-423. [CrossRef]

56. Ministerio de Salud y Protección Social. Resolución número 2465 de 2016. Por la cual se adoptan los indicadores antropométricos, patrones de referencia y puntos de corte para la clasificación antropométrica del estado nutricional de niñas, niños y adolescentes menores de 18 años de edad, adultos de 18 a 64 años de edad y gestantes adultas y se dictan otras disposiciones; Ministerio de Salud y Protección Social: Bogotá, Colombia, 2016.

57. Pérez-Ordaz, R.; Aznar, M.; Nuviala, R.; Nuviala, A. Evaluation of extracurricular sports activities as an educational element for sustainable development in educational institutions. Sustainability 2019, 11, 3474. [CrossRef]

(C) 2019 by the authors. Licensee MDPI, Basel, Switzerland. This article is an open access article distributed under the terms and conditions of the Creative Commons Attribution (CC BY) license (http://creativecommons.org/licenses/by/4.0/). 